Supporting Information for

\title{
Determination of the Low Hg Accumulation in Rabbitfish (Siganus canaliculatus) by Various Elimination Pathways: Simulation by a Physiologically Based Pharmacokinetic Model
}

\author{
Xun Wang ${ }^{\mathrm{a}}$, Wen-Xiong Wangb,* \\ ${ }^{a}$ Joint Laboratory of Guangdong Province and Hong Kong Region on Marine \\ Bioresource Conservation and Exploitation, College of Marine Sciences, South China \\ Agricultural University, Guangzhou, 510642, China \\ ${ }^{b}$ School of Energy and Environment and State Key Laboratory of Marine Pollution, \\ City University of Hong Kong, Kowloon, Hong Kong \\ *Corresponding author:ww.wang@cityu.edu.hk
}

Number of pages: 11

Number of figures: 6

Number of tables: 2 
Table S1. The dissolved $\mathrm{Hg}(\mathrm{II})$ concentration in the seawater of waterborne treatment after $\mathrm{Hg}(\mathrm{II})$ administration. Seawater was sampled every $3 \mathrm{~h}$ until renewed.

\begin{tabular}{cc}
\hline Sampling point & $\begin{array}{c}\text { Dissolved } \mathrm{Hg}(\mathrm{II}) \text { concentration } \\
\left(\mu \mathrm{g} \mathrm{L}^{-1}\right)\end{array}$ \\
\hline $0 \mathrm{~h}$ & $5.0 \pm 0.25 \mathrm{a}^{*}$ \\
$3 \mathrm{~h}$ & $4.8 \pm 0.45 \mathrm{a}$ \\
$6 \mathrm{~h}$ & $4.9 \pm 0.50 \mathrm{a}$ \\
$9 \mathrm{~h}$ & $4.7 \pm 0.53 \mathrm{a}$ \\
$12 \mathrm{~h}$ & $4.8 \pm 0.47 \mathrm{a}$ \\
\hline
\end{tabular}

* Same letters indicate no significant difference between sampling point at the level of $p<0.05$ 


\section{Detailed information in the PBPK modeling}

In the present study, the flux between compartments was assumed to follow first-order kinetics, expressed by the following equation:

$$
\operatorname{Flux}_{(i, j)}=\mathrm{k}_{(i, j)} \bullet \mathrm{Q}_{j}
$$

$\mathrm{k}_{(i, j)}\left(\mathrm{d}^{-1}\right)$ is the rate coefficient between the compartments, where $i$ refers to the receptor compartment and $j$ refers to the source. $\mathrm{Q}_{j}$ is the total amount of $\mathrm{Hg}$ in the $j$ th compartment at time $t$, and equals to the product of $\mathrm{Hg}$ concentration in the $j$ th compartment $\left(\mathrm{C}_{j}\right)$ and its fresh weight $\left(\mathrm{w}_{j}\right)$. The total weight of blood is calculated by assuming $60 \mathrm{ml}$ blood/kg tissue in teleosts and $1 \mathrm{~mL}$ blood $\approx 1 \mathrm{~g}$ (Olson, 1992).

For waterborne-exposed fish, branchial uptake was considered as the major pathway for $\mathrm{Hg}$ absorption from water. $\mathrm{k}_{\mathrm{w}}$ is the uptake rate coefficient of $\mathrm{Hg}$ (II) transferred from water to gill. The dosage of $\mathrm{Hg}(\mathrm{II})$ exposed to the gills could be calculated from the water flow rate passed by the gills during daily respiration. The ventilation volumes (V) of rabbitfish can be expressed as following:

$$
\mathrm{V}=R_{O_{2}} /\left(\alpha \cdot C_{w, O_{2}}\right)
$$

$R_{O_{2}}$ is the oxygen consumption rate $\left(\mathrm{mg} \mathrm{O}_{2} \mathrm{~h}^{-1}\right)$ and assumed to be $11.4 \mathrm{mg} \mathrm{O}_{2} \mathrm{~h}^{-1}$ for $20 \mathrm{~g}$ fish in our study according to the measured respiration rates of marbled rabbitfish ( $S$. rivulatus) (Babikian et al., 2017). $\alpha$ is the assimilation efficiency of oxygen (assumed to be 0.6) (Barber, 2003) and $C_{w, O_{2}}$ is the dissolved oxygen concentration of the ambient water (6 $\mathrm{mg} \mathrm{O}_{2} \mathrm{~L}^{-1}$ in sand-filtered seawater). Thus, the ventilation volume (V) in our study was calculated to be $3.17 \mathrm{~L} \mathrm{~h}^{-1}$ (i.e., $76 \mathrm{~L}$ water flowed through the gills per day). Considering that the dissolved $\mathrm{Hg}(\mathrm{II})$ concentration in the water was $5.0 \mu \mathrm{g} \mathrm{L}^{-1}$, it can be calculated that $380 \mu \mathrm{g}$ $\mathrm{Hg}(\mathrm{II})$ was exposed to the gills per fish per day during respiration. The dosage of waterborne $\mathrm{Hg}$ (II) exposed to the gills was $19 \mu \mathrm{g} \mathrm{g}^{-1} \mathrm{ww} \mathrm{d}^{-1}$. On the other hand, the intestine could be another potential site for dissolved $\mathrm{Hg}$ (II) exposure since marine fish need to drink seawater to regulate osmotic pressure. Assuming that the drinking rate is $0.12 \mathrm{~L} \mathrm{~kg}^{-1} \mathrm{ww} \mathrm{d}^{-1}$ (Zhang and Wang, 2007), the dosage of dissolved $\mathrm{Hg}(\mathrm{II})$ exposed to intestine was calculated to be $0.6 \mathrm{ng}$ $\mathrm{g}^{-1} \mathrm{ww} \mathrm{d}^{-1}$. Compared to the branchial exposure, the contribution of seawater ingestion to dissolved $\mathrm{Hg}(\mathrm{II})$ uptake was minimal and could be ignored. Thus, the intestinal uptake of dissolved $\mathrm{Hg}$ (II) was not considered in the modeling for waterborne-exposed fish.

To simulate the physiological process (uptake and elimination) in the digestive tract, the intestine compartment was divided into two independent sub-compartments: Chyme and gut wall. Chyme is the semifluid mass of food mixed with digestive solution and can be considered as the "precursor" of feces. Hg in the chyme could be absorbed by the gut tissue $\left(\operatorname{Flux}_{(2,7)}\right)$. The residual $\mathrm{Hg}$ in the chyme were finally eliminated to outside through the feces $\left(\operatorname{Flux}_{(0,7)}\right)$. Concentrations of $\mathrm{Hg}$ in the intestine can be expressed by the following equation:

$$
\mathrm{C}_{\text {intestine }}=\left(\mathrm{Q}_{\text {chyme }}+\mathrm{Q}_{\text {gut wall }}\right) /\left(\mathrm{w}_{\text {chyme }}+\mathrm{w}_{\text {gut wall }}\right)
$$

where $\mathrm{C}_{\text {intestine }}$ refers to the determined value of $\mathrm{MeHg}$ or $\mathrm{Hg}(\mathrm{II})$ for the intestine, whereas $\mathrm{Q}_{\text {chyme }}$ and $\mathrm{Q}_{\text {gut wall }}$ represent the total amount of $\mathrm{MeHg}$ or $\mathrm{Hg}(\mathrm{II})$ in the chyme and the gut wall at time $t$. It should be noted that $\mathrm{Q}_{\text {chyme }}$ and $\mathrm{Q}_{\text {gut wall }}$ were fitted by the modeling. $\mathrm{w}_{\text {gut wall }}$ refers to the fresh weight of the empty intestine and was obtained from the starved fish in the preliminary experiment. For the convenience in simulation, $\mathrm{w}_{\text {chyme }}$ was assumed to be a constant and equaled to be the weight of fed food in one meal.

The fish weights parameters are listed in the below Table: 
Table S2. Fish weights parameters used for calibration. ${ }^{a}$ fresh weight.

\begin{tabular}{llll}
\hline Symbol & Value & Units & Description \\
\hline $\mathrm{W}_{\text {total }}$ & 30 & $\mathrm{~g}^{\mathrm{a}}$ & Whole fish weight \\
$\mathrm{V}$ & 1.8 & $\mathrm{ml}$ & Blood volume \\
$\mathrm{W}_{\mathrm{I}}$ & 2.86 & $\mathrm{~g}$ & Weight of intestine without food ingestion \\
$\mathrm{W}_{\mathrm{G}}$ & 0.64 & $\mathrm{~g}$ & Weight of gill \\
$\mathrm{W}_{\mathrm{L}}$ & 0.67 & $\mathrm{~g}$ & Weight of liver \\
$\mathrm{W}_{\mathrm{K}}$ & 0.06 & $\mathrm{~g}$ & Weight of kidney \\
$\mathrm{W}_{\mathrm{C}}$ & 23.97 & $\mathrm{~g}$ & Weight of carcass \\
$\mathrm{W}_{\mathrm{Y}}$ & 0.2 & $\mathrm{~g}$ & Weight of chyme \\
\hline
\end{tabular}


Fig. S1 Concentrations of $\mathrm{MeHg}(\mathrm{a}, \mathrm{b})$ in different compartments (blood, gill, carcass, intestine, liver and kidney) of rabbitfish under dietary/waterborne $\mathrm{Hg}(\mathrm{II})$ exposure, and $\mathrm{Hg}(\mathrm{II})$ (c) concentrations dietary under MeHg exposure. Data are means $\pm \mathrm{SD}(\mathrm{n}=4)$.
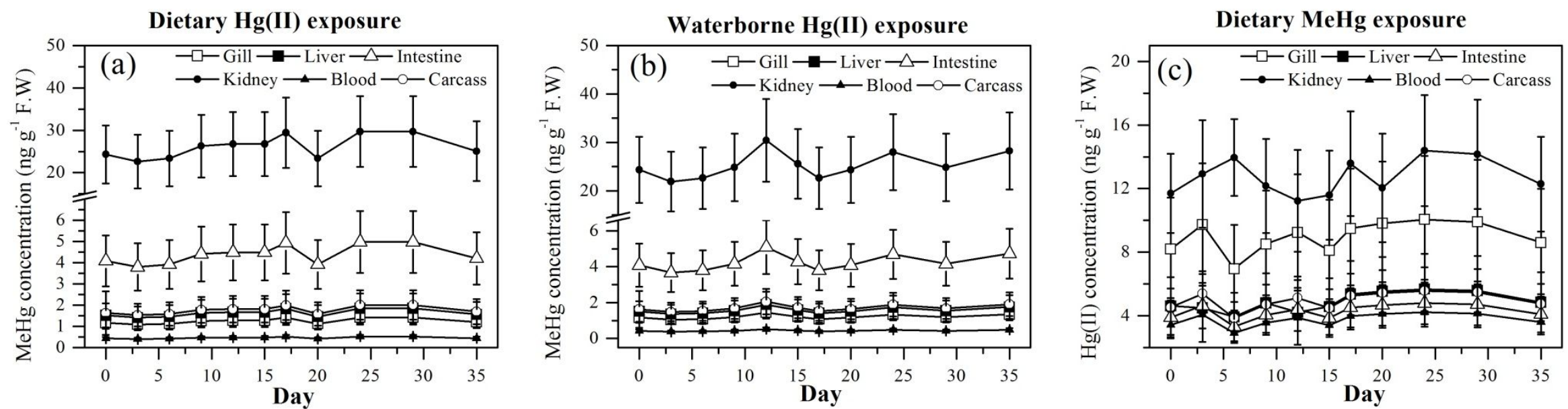
Fig. S2 Concentrations of $\mathrm{Hg}$ (II) (a) and $\mathrm{MeHg}$ (b) in different compartments (blood, gill, carcass, intestine, liver and kidney) of rabbitfish fed with clean fish diet. Data are means $\pm \mathrm{SD}(\mathrm{n}=4)$.
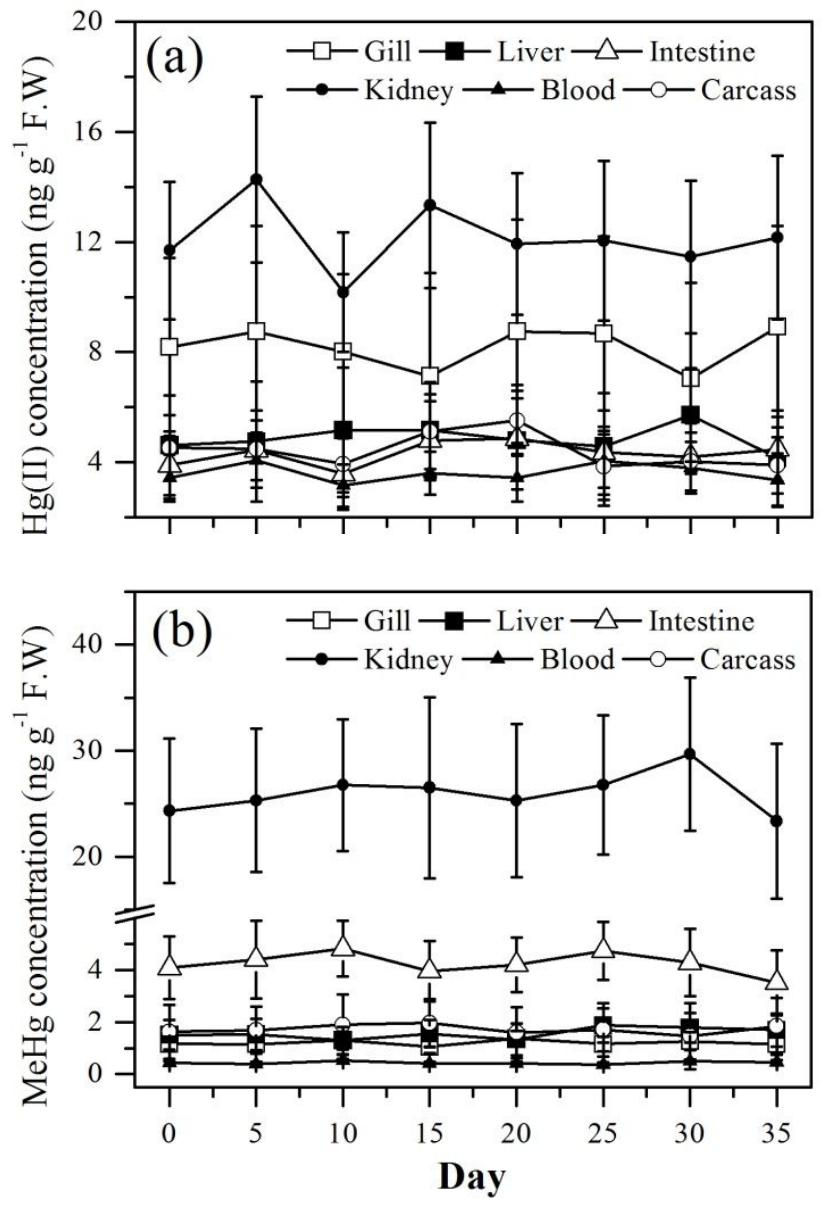
Fig. S3 The observed plots and fitted curves of $\mathrm{Hg}(\mathrm{II})$ in blood (a), intestine (b), gill (c), liver (d), kidney (e) and carcass (f) of rabbitfish in the dietary $\mathrm{Hg}$ (II) treatment during exposure $(15 \mathrm{~d})$ and depuration $(20 \mathrm{~d})$. Data are means $\pm \mathrm{SD}(\mathrm{n}=4)$.
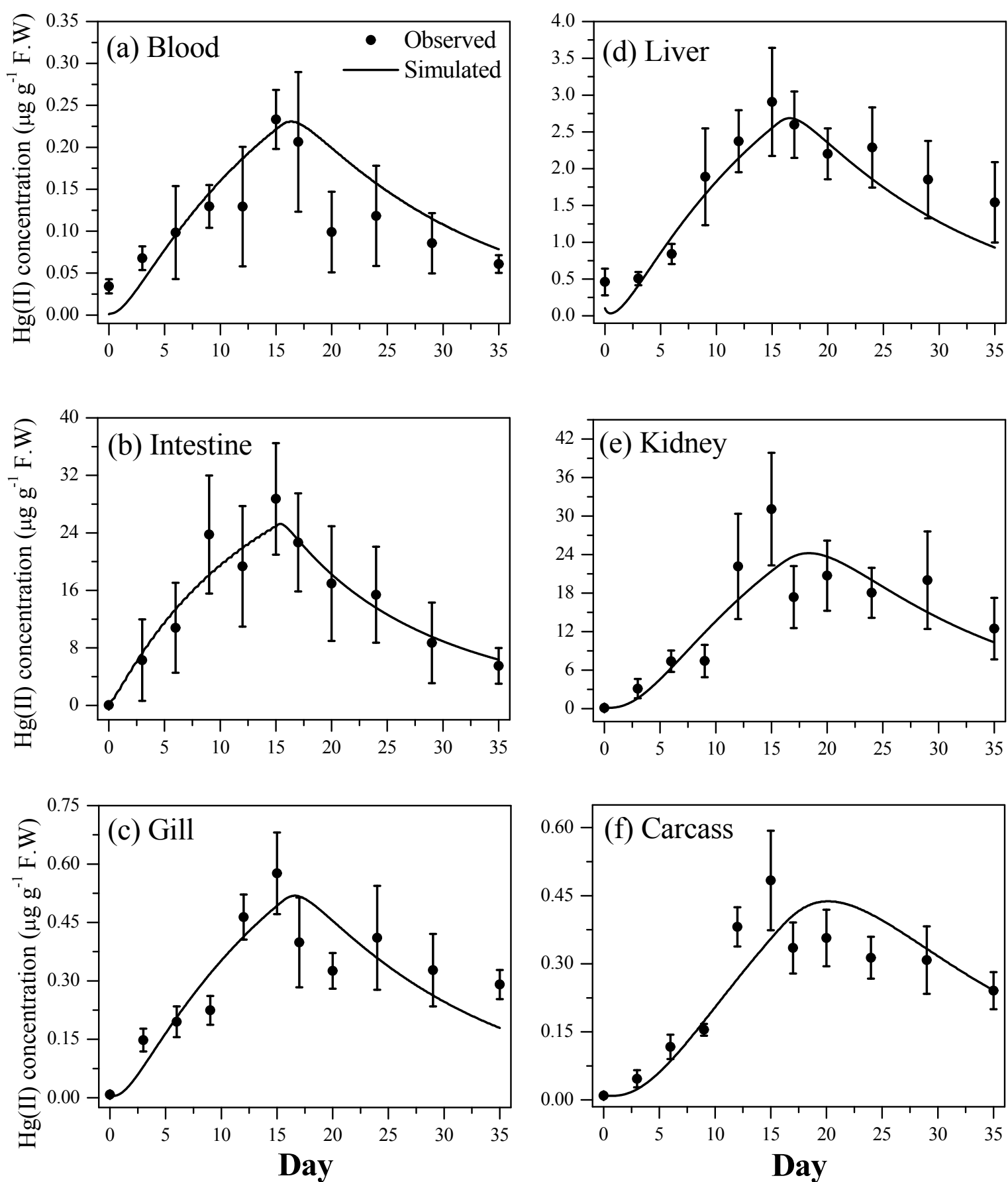

Day 
Fig. S4 The observed plots and fitted curves of $\mathrm{Hg}(\mathrm{II})$ in blood (a), intestine (b), gill (c), liver (d), kidney (e) and carcass (f) of rabbitfish in the waterborne $\mathrm{Hg}$ (II) treatment during exposure $(15 \mathrm{~d})$ and depuration $(20 \mathrm{~d})$. Data are means $\pm \mathrm{SD}(\mathrm{n}=4)$.
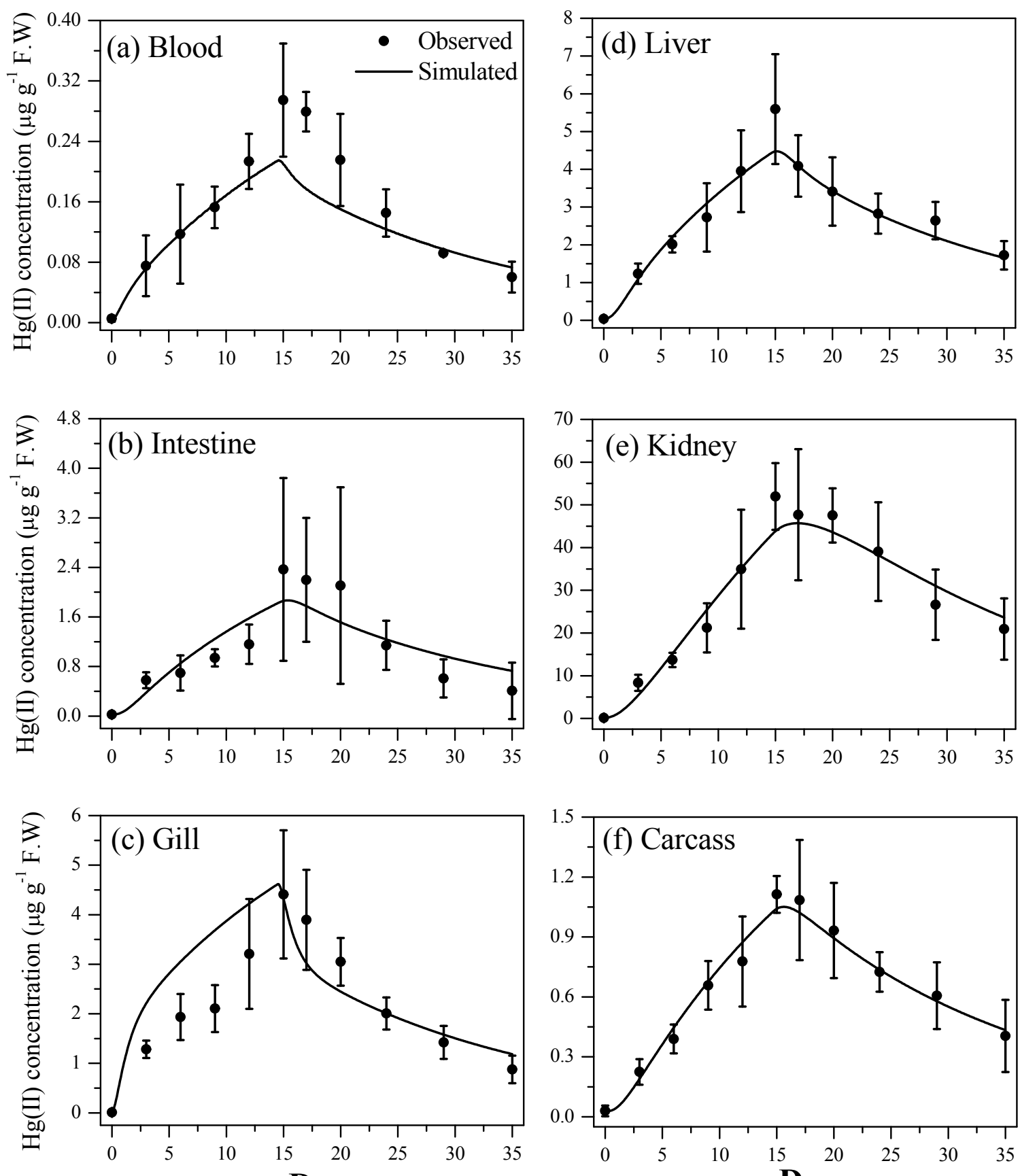

Day

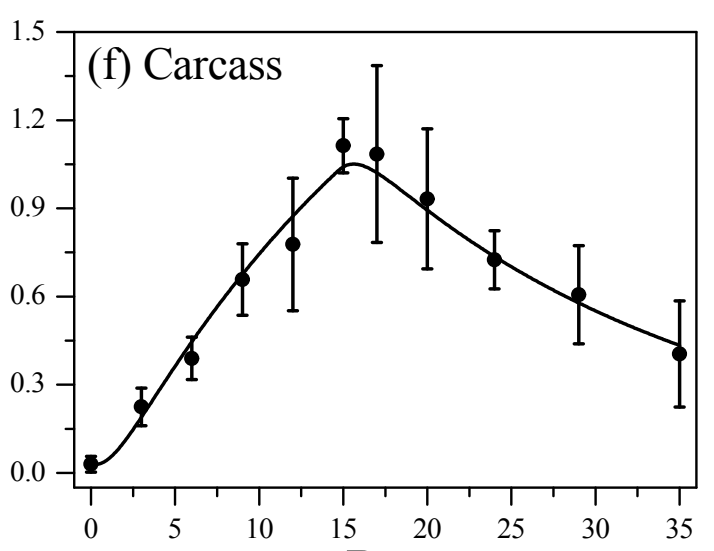

Day 
Fig. S5 The observed plots and fitted curves of $\mathrm{MeHg}$ in blood (a), intestine (b), gill (c), liver (d), kidney (e) and carcass (f) of rabbitfish in the MeHg treatment during exposure $(15 \mathrm{~d})$ and depuration $(20 \mathrm{~d})$. Data are means $\pm \mathrm{SD}(\mathrm{n}=4)$.
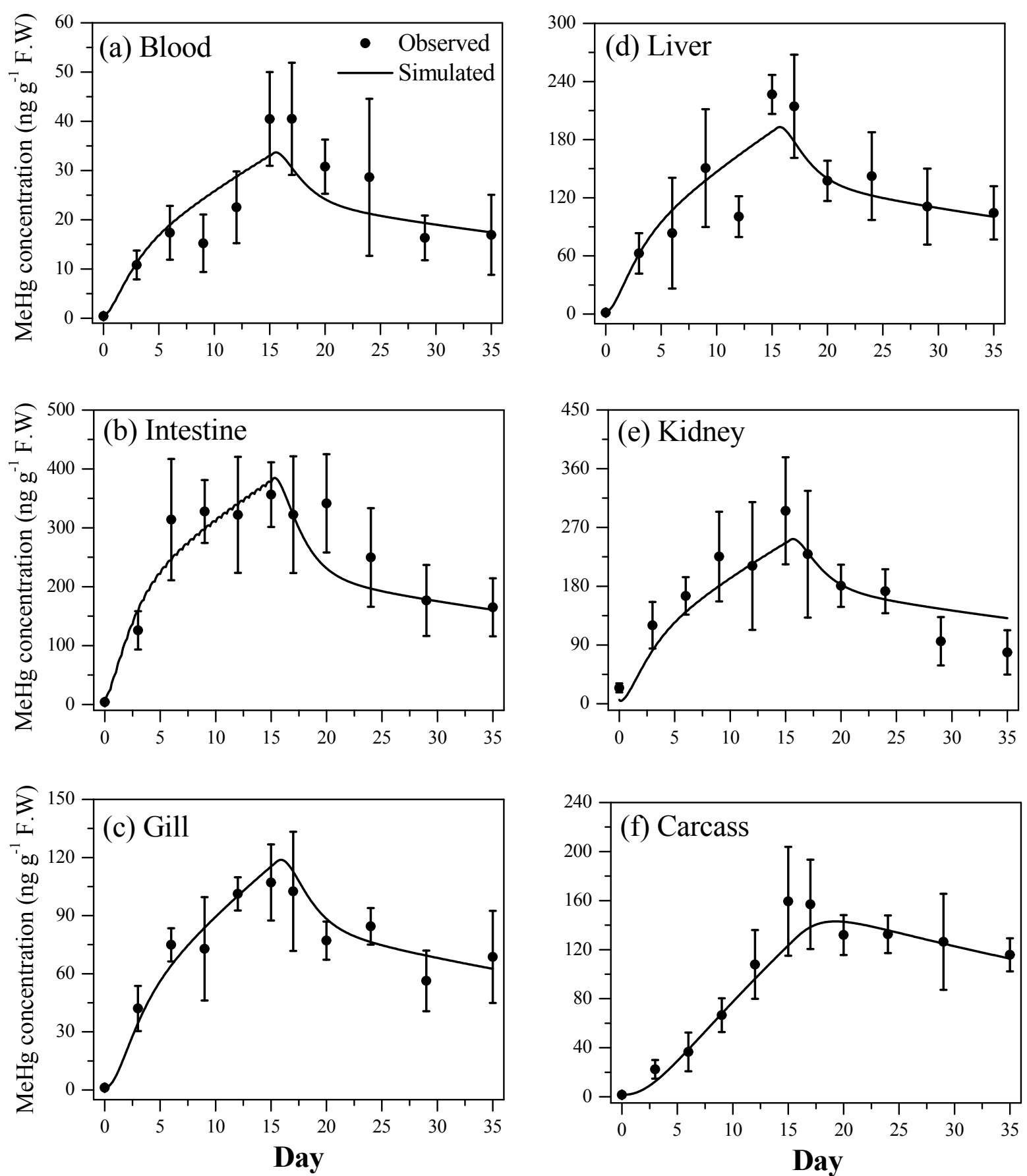
Fig. S6 Whole-body concentrations of $\mathrm{Hg}(\mathrm{II})$ (a) and $\mathrm{MeHg}$ (b) of rabbitfish under different exposure scenarios.
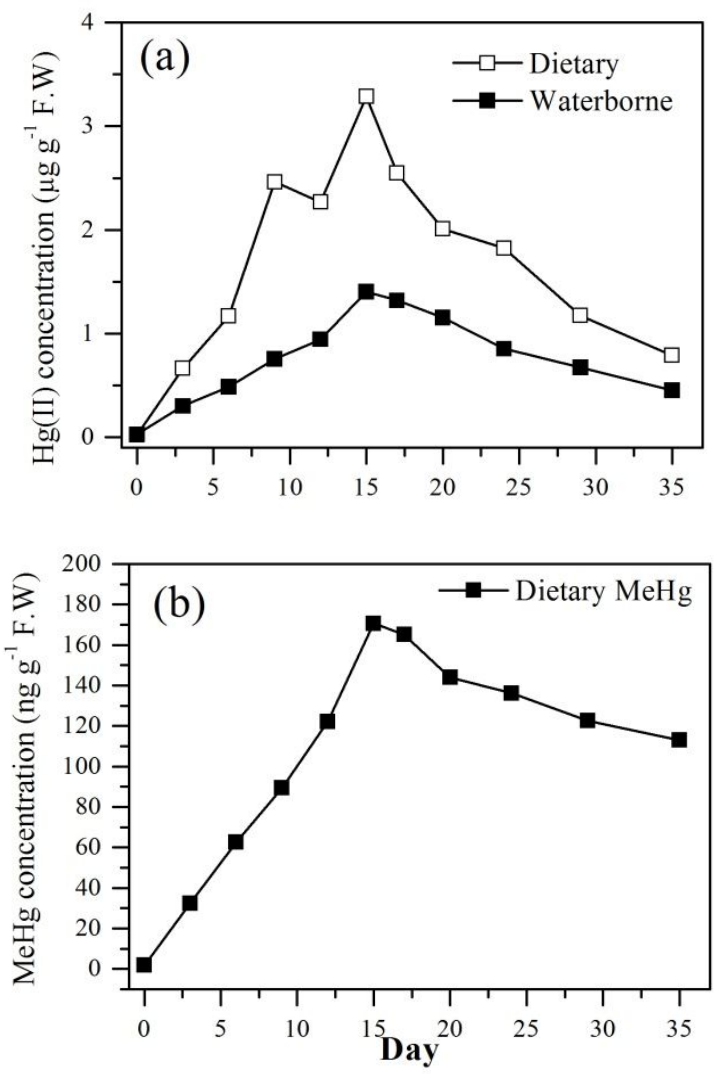


\section{References}

Babikian J, Nasser N, Saoud IP. Effects of salinity on standard metabolic rate of juvenile marbled spinefoot (Siganus rivulatus). Aquaculture Research. 2017. 48: 2561-2566.

Barber MC. A review and comparison of models for predicting dynamic chemical bioconcentration in fish. Environmental Toxicology and Chemistry. 2003. 22: 1963-1992.

Olson KR. 3 Blood and extracellular fluid volume regulation: Role of the renin-angiotensin system, kallikrein-kinin system, and atrial natriuretic peptides. Fish physiology. 1992. 12: 135-254.

Zhang L, Wang W-X. Waterborne cadmium and zinc uptake in a euryhaline teleost Acanthopagrus schlegeli acclimated to different salinities. Aquatic Toxicology. 2007. 84: 173-181. 